DOI: 10.52362/jmijayakarta.v1i2.448

\title{
PERANCANGAN APLIKASI PENCARIAN RUTE WISATA KULINER BERBASIS ANDROID MENGGUNAKAN ALGORITMA DIJKSTRA DI KOTA TANGERANG SELATAN
}

\author{
Maulana Syepanda ${ }^{1}$, Zulhalim ${ }^{2}$, Rachmawaty Haroen ${ }^{3}$ \\ Program Studi Teknik Informatika ${ }^{1}$, Teknik Informatika ${ }^{2}$, Sistem Informasi ${ }^{3}$ \\ Sekolah Tinggi Manajemen Informatika dan Komputer Jayakarta \\ msyepanda@gmail.com ${ }^{1}$, zulhalim@stmik.jayakarta.ac.id ${ }^{2}$, rachmawaty@stmik.jayakarta.ac.id ${ }^{3}$
}

\begin{abstract}
ABSTRAK
Tangerang Selatan merupakan salah satu kota wisata yang memiliki destinasi kuliner yang digemari oleh banyak wisatawan. Kesulitan para wisatawan dalam menemukan tempat wisata yang terletak di dalam gang atau berjarak beberapa puluh meter dari jalan raya di wilayah Tangerang Selatan perlu diantisipasi. Perancangan aplikasi rute wisata kuliner merupakan suatu alternatif yang dapat meminimalisir atau bahkan mengeliminasi kesulitan tersebut. Penelitian ini dilakukan untuk mengembangkan sebuah aplikasi yang dibuat dengan bahasa pemograman java dengan SDK dan aplikasi bantuan dari Google Maps API, serta Location Based Service (LBS) yang menyediakan informasi posisi geoGrafis tempat kuliner. Pembuatan aplikasi ini melalui beberapa tahapan penting, diantaranya analisis kebutuhan, perancangan, implementasi rancangan, dan pengujian sistem yang dibuat. Penelitian dan perancangan aplikasi ini menggunakan metode waterfall dan menerapkan algoritma dijkstra berbasis android. Penggunaan aplikasi ini didahului dengan pengujian pada algoritma Dijkstra dan pengujian black box, sehingga aplikasi ini dapat digunakan sebagaimana mestinya. Berdasarkan penelitian yang sudah dilakukan, aplikasi ini dapat digunakan untuk membantu dan mempermudah wisatawan untuk menemukan dan menentukan rute terpendek menuju ke lokasi wisata kuliner yang ada di Kota Tangerang Selatan.
\end{abstract}

Kata kunci: Wisata Kuliner, Algoritma Dijkstra, Android

Abstract: South Tangerang is a city that has a culinary destination that is favored by many tourists. The difficulty of travelers in finding a place that is located in the alley or within a few tens of meters from the highway in South Tangerang need to be anticipated.. Application design the route of culinary tourism is an alternative that can minimize or even eliminate such difficulties. This research was conducted to develop an application created with the java programming language with the SDK and the application help of Google Maps API, and Location Based Service provides information on the geographical position of the place of food. The making of this app through several important stages, including requirements analysis, design, design implementation, and testing of the system are made.. Research and design of this application using the waterfall method and applying the algorithm of Dijkstra based on android. Use of this application is preceded by testing on the algorithm of Dijkstra and black box testing, so this app can be used properly. Based on the research that has been done, this application can be used to assist and facilitate tourists to find and to determine the shortest route to the location of the culinary tourism in the City of South Tangerang.

Keywords: Culinary, Dijkstra Algorithm, Android

\section{PENDAHULUAN}

@e Ciptaan disebarluaskan di bawah Lisensi Creative Commons Atribusi 4.0 Internasional. http://journal.stmikjayakarta.ac.id/index.php/JMIJayakarta 


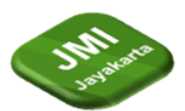

DOI: $10.52362 /$ jmijayakarta.v1i2.448

Undang-undang Nomor 10 Tahun 2019 menyebutkan bahwa industri pariwisata adalah kegiatan usaha pariwisata yang yang saling berkaitan guna menghasilkan barang dan/atau jasa bagi pemenuhan kebutuhan wisatawan dalam penyelenggaraan pariwisata. Industri pariwisata dilakukan untuk mendapatkan keuntungan dalam berbagai bidang, diantaranya perhotelan, kebudayaan, rekreasi dan hiburan, biro perjalanan, guide business, souvernir, dan kuliner perestoranan. Industri pariwisata kuliner saat ini sedang mengalami perkembangan yang cukup pesat, terutama kuliner yang berkaitan dengan penyediaan makanan dan minuman. Menurut UNWTO, Global Report on Shopping Tourism pada tahun 2016, wisata belanja menjadi bagian yang penting dalam destinasi wisata. Pengeluaran untuk melakukan kegaitan belanja makanan mencapai $16 \%$, dan kunjungan suatu wisatawan untuk mengunjungi kuliner di suatu daerah mencapai $97 \%$. Beragam sajian ditawarkan mulai dari makanan khas daerah yang bersifat tradisional dan unik hingga makanan cepat saji yang bersifat modern. Lokasi kuliner yang semakin banyak mengakibatkan para penikmat kuliner mengalami kesulitan untuk mencari lokasi tempat makan yang sesuai keinginan. Para penikmat kuliner membutuhkan waktu yang cukup lama untuk mendatangi langsung lokasi kuliner yang mereka inginkan. Masih begitu banyak kuliner yang terletak di dalam gang dan berjarak beberapa meter dari jalan raya, sehingga menyebabkan tempat kuliner tersebut tidak terlihat oleh banyak orang terutama wisatawan yang berasal dari luar Kota Tangerang Selatan. Salah satu permasalahan yang saat ini perlu diantisipasi adalah para penikmat kuliner dari luar kota suatu wilayah yang ingin menikmati wisata kuliner di luar kota, khususnya Kota Tangerang Selatan. Oleh karena itu, dibutuhkan suatu aplikasi yang memiliki aspek fungsionalitas dalam pencarian tempat wisata kuliner terdekat berdasarkan lokasi keberadaan pengguna dan menyediakan informasi yang lengkap, seperti pencarian lokasi restoran, warung makan, dan cafe. Aspek-aspek tersebut diharapkan dapat memberikan nilai tambah bagi aplikasi yang akan dibangun agar dapat memenuhi kebutuhan pengguna dalam pencarian lokasi tempat wisata kuliner di Kota Tangerang Selatan. Dengan demikian, pengguna dapat mengetahui infomasi tentang lokasi dan mendapatkan lokasi yang akurat. Diharapkan di masa depan, aplikasi ini akan semakin mempermudah setiap aktivitas pencinta kuliner dalam menemukan tempat makan yang terletak di wilayah Kota Tangerang Selatan.

\section{MATERIAL DAN METODE}

\subsection{Algoritma Dijkstra}

Algoritma Dijkstra ditemukan oleh Edger Wybe Dijkstra pada tahun 1959. Algoritma dijkstra dapat memecahkan masalah pencarian jalur terpendek dari suatu Graf pada setiap simpul yang bernilai tidak negatif. Dijkstra menurut Al-Amin (2017) merupakan algoritma yang sering digunakan untuk memecahkan masalah yang berhubungan dengan suatu optimasi dalam pencarian jalur terpendeknya, dengan mencari bobot yang paling minimal dari suatu Graf berbobot. Jarak terpendek akan diperoleh dari dua atau lebih titik dari suatu Graf dan nilai total yang didapat adalah yang bernilai paling kecil. Misalkan $\mathrm{G}$ adalah Graf berarah berlabel dengan titik-titik $V(G)=$ $\left\{v_{1}, v_{2} \ldots, v_{n}\right\}$ dan path terpendek yang dicari adalah dari $v_{1}$ ke $v_{n}$. Algoritma Dijkstra dimulai dari titik $v_{1}$.

Dalam iterasinya, algoritma akan mencari satu titik yang jumlah bobotnya dari titik 1 terkecil. Titik-titik yang terpilih dipisahkan, dan titik-titik tersebut tidak diperhatikan lagi dalan iterasi berikutnya. Langkah-langkah dalam menentukan lintasan terpendek pada algoritma Dijkstra (Budihartanti, 2016) yaitu:

a. Melakukan inisialisasi.

b. Memilih node sumber sebagai node awal, menginisialisasikan dengan ' 1 '.

c. Membentuk tabel yang terdiri dari node, status, bobot, dan predecessor. Melengkapi kolom bobot yang diperoleh dari jarak node sumber ke semua node yang langsung terhubung dengan node sumber tersebut.

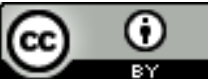

Ciptaan disebarluaskan di bawah Lisensi Creative Commons Atribusi 4.0 Internasional.

http://journal.stmikjayakarta.ac.id/index.php/JMIJayakarta 
DOI: $10.52362 /$ jmijayakarta.v1i2.448

d. Menetapkan sebagai node terpilih jika node sumber ditemukan.

e. Memberikan label sementara nilai tak hingga pada setiap node.

f. Menentukan node sementara yang terhubung pada node yang sudah terpilih sebelumnya dan merupakan bobot terkecil dilihat dari tabel, lalu mententukan sebagai node terpilih berikutnya.

g. Menghapus label sementara dan menetapkan node terpilih dengan label permanen dan meperbaharui node yang langsung terhubung.

h. Memeriksa node yang dikunjungi, apakah node sudah pernah dikunjungi. Membandingkan bobot nilai baru dengan bobot nilai lama.

i. Mengumpulkan node terpilih atau predecessor merupakan rangkaian yang menunjukan lintasan terpendek jika node yang terpilih merupakan node tujuan.

j. Menampilkan hasil jalur terpendek pada peta selesai.

\subsection{Graf}

Teori graf memiliki banyak terapan dalam kehidupan sehari-hari sampai saat ini. graf digunakan untuk merepresentasikan objek-objek diskrit dan hubungan antara objek-objek tersebut. Representasi visual graf banyak ditemui pada permasalahan di dunia nyata. Contoh salah satu representasi visual dari graf adalah peta.

\section{a. Jenis-Jenis Graf}

Klasifikasi pada graf cukup luas, klasifikasi tersebut bergantung pada faktor-faktor yang membedakannya. Berdasarkan orientasi arah pada sisinya, maka secara umum graf dibedakan atas dua jenis sebagai berikut (Munir, 2016):

1) Graf tidak berarah (undirected graph)

Graf yang sisisnya tidak memiliki orientasi arah disebut graf tidak berarah. Pada graf tidak berarah, urutan pasangan simpul yang dihubungkan oleh sisi tidak diperhatikan. Jadi, $(\mathrm{u}, \mathrm{v})=(\mathrm{v}, \mathrm{u})$ adalah sisi yang sama.

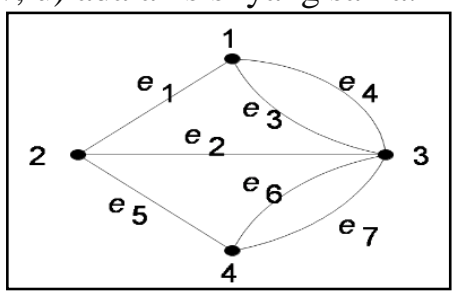

Gambar 2.2

1) Graf berarah (directed graph) Graf Tak Berarah

Graf berarah adalah graf yans _...... ...... ....... rikan orientasi arah. Pada graf berarah (u, v) dan (v, u) menyatakan dua buah sisi yang berbeda. Dengan kata lain dapat ditulis $(\mathrm{u}, \mathrm{v}) \neq(\mathrm{v}, \mathrm{u})$.

\subsection{Android}

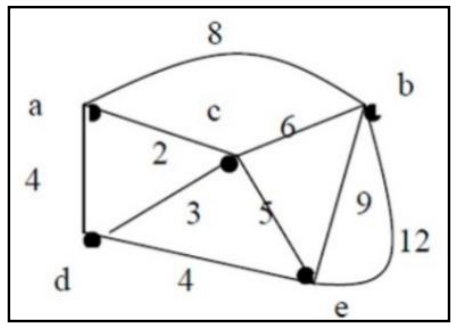

Gambar 2.1.

Graf Berarah

Menurut Safaat (2011) Pemrograman apl tablet PC berbasis Android. Android merupakan suatu software (perangkat lunak) yang digunakan pada mobile device (perangkat berjalan) yang meliputi sistem operasi, middleware, dan aplikasi inti. Android Standard Development 


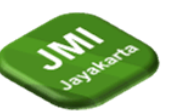

DOI: $10.52362 /$ jmijayakarta.v1i2.448

Kit (SDK) menyediakan alat dan Application Programming Interface (API) yang diperlukan untuk memulai pengembangan aplikasi pada platform Android menggunakan bahasa pemrograman Java, yaitu kode Java yang terkompilasi dengan data dan file resources yang dibutuhkan aplikasi dan digabungkan oleh app tools menjadi paket Android.

\section{a. Android SDK (Software Development Kit)}

Android SDK adalah tools API (Application Programming Interface) yang diperlukan untuk mulai mengembangkan aplikasi pada platform Android menggunakan bahasa pemograman Java. Android merupakan subset perangkat lunak untuk ponsel yang meliputi sistem operasi, middleware dan aplikasi kunci yang dirilis oleh Google. Saat ini disediakan Android SDK (Software Development Kit) sebagai alat bantu dan API untuk mulai mengembangkan aplikasi pada platform Android menggunakan bahasa pemograman Java (Purwaningsih, 2017).

\subsection{Google Maps API}

Google Maps API adalah layanan API gratis yang diberikan google dalam bentuk suatu peta dunia yang dapat digunakan untuk melihat suatu daerah. API secara sederhana bisa diartikan sebagai kode program yang merupakan antarmuka atau penghubung antara aplikasi atau web yang kita buat dengan fungsi-fungsi yang dikerjakan (Mufti, 2015). Misalnya dalam hal ini Google API berarti kode program (yang disederhanakan) yang dapat kita tambahkan pada aplikasi atau web kita untuk mengakses/ menjalankan/ memanfaatkan fungsi atau fitur yang disediakan Google.

\subsection{Unifield Modeling Language (UML)}

\section{a. Pengertian Unifield Modeling Language (UML)}

Unifed Modelling Language (UML) adalah salah satu standar bahasa yang digunakan di dunia industri untuk mendefinisikan requirement, membuat analisis dan desain, serta menggambarkan arsitektur dalam pemrograman beorientasi objek. UML muncul karena adanya kebutuhan pemodelan visual untuk menspesifikasikan, menggambarkan, membangun, dan mendokumentasikan perangkat lunak. UML merupakan bahasa visual untuk pemodelan dan komunikasi mengenai sebuah sistem dengan menggunakan diagram dan teks-teks pendukung. Penggunaan UML tidak terbatas pada metodologi tertentu, meskipun pada kenyataannya UML paling banyak digunakan pada metodologi berorientasi objek (Putra, 2019).

b. Konsep Pemodelan Unified Modeling Language (UML)

Tidak ada batasan di antara berbagai konsep dan konstruksi dalam UML. Namun, untuk menyederhanakannya, sejumlah besar konsep dan dalam UML dibagi menjadi beberapa view (Nugroho, 2010). Pada dasarnya, sejumlah konstruksi pemodelan UML aspek tertentu dari sistem atau perangkat lunak yang sedang dikembangkan direpresentasikan dalam view. View-view dibagi menjadi tiga area utama, yaitu: klasifikasi struktural (structural classification), perilaku dinamis (dinamic behaviour), serta pengolahan atau manajemen model (model management) (Nugroho, 2010).

\subsection{MySQL}

MySQL merupakan salah satu database server yang cukup terkenal dan termasuk jenis Relational Database Management System (RDBMS). My SQL dikembangkan oleh David Axmark dan kawankawan pada tahun 1994 yang bertujuan untuk mengembangkan aplikasi berbasis web pada client (Palit, 2015). MySQL digunakan untuk membuat database. Database memuat kumpulan informasi yang disimpan secara sistematik dan dapat diperiksa dengan suatu program untuk memperoleh informasi basis data tersebut (Saputra, 2020).

\subsection{PhpMyAdmin}

PhpMyAdmin merupakan sebuah aplikasi opensource untuk menangani administrasi database pada MySQL yang ditulis dalam bahasa pemograman PHP melalui jaringan local maupun internet. 
DOI: 10.52362/jmijayakarta.v1i2.448

PhpMyAdmin dapat mengelola basis data, tabel-tabel, relasi, bidang (fields), indeks, user, perijinan, dan sebagainya. Fungsi PhpMyAdmin adalah untuk memudahkan pengoperasian dalam pengaturan dan pengolahan database yang terdapat pada MySQL (Standsyah, 2017).

\section{$2.8 X A M P P$}

$X A M P P$ merupakan perangkat lunak yang dikompilasikan dari beberapa program, dan menggabungkan tiga aplikasi menjadi satu, yaitu Apache, MySQL 6, dan PhpMyAdmin. Penggunaan $X A M P P$ ini dapat memudahkan pekerjaan karena dapat melakukan instalasi tiga aplikasi dalam satu waktu sekaligus. XAMPP dikembangkan ole Apache Frinds, dan didirkan oleh Oswalad Seidler dan Kay Vogelgesang pada tahun 2002.

\subsection{LBS (Location Based Service)}

Location based services adalah layanan berbasis lokasi atau gambaran teknologi yang digunakan untuk menemukan lokasi perangkat yang pengguna gunakan. Layanan ini menggunakan teknologi Global Positioning Service (GPS) dan cell-based location dari Google. LBS terdiri dari beberapa komponen di antaranya mobile devices, communication network, position component, dan service and content provider. Mobile devices merupakan komponen yang sangat penting. Piranti mobile tersebut di antaranya adalah smartphone, PDA, dan lainnya yang dapat berfungsi sebagai alat navigasi atau seperti halnya alat navigasi berbasis GPS (Djafar, 2016).

\subsection{JSON (JavaScript Object Notation)}

JSON (JavaScript Object Notation) adalah format pertukaran data (lightweight datainterchange format), mudah dibaca dan ditulis oleh manusia, serta mudah diterjemahkan dan dibuat (generate) oleh computer. Format ini dibuat berdasarkan bagian dari Bahasa Pemprograman JavaScript, standar ECMA-262 Edisi ke-3 Desember 1999. JSON merupakan format teks yang tidak bergantung pada bahasa pemprograman apapun karena menggunakan gaya Bahasa yang umum digunakan oleh programmer keluarga $\mathrm{C}$ termasuk $\mathrm{C}$, C++, C\#, Java, JavaScript, Perl, Python dan lain-lain (Susetyo, 2018).

\section{HASIL DAN PEMBAHASAN}

\subsection{Penelitian}

Pada penelitian kali ini, peneliti menggunakan pendekatan kualitatif. Pada pendekatan kualitatif, peneliti lebih menekankan pada pemahaman mengenai permasalahan dalam kehidupan sehari-hari berdasarkan kondisi realitas. Hal ini menyebabkan bentuk desain yang bervariasi, fleksibel, dan dapat diubah sesuai dengan rencana yang sudah dibuat sebelumnya (Lestari, 2017). Metode yang digunakan dalam penelitian ini adalah design and creation. Dalam hal ini, peneliti menggambarkan objek penelitian, dan juga mengembangkan suatu produk berdasarkan penelitian yang sudah dilakukan. Pada penelitian kali ini, peneliti yang menetapkan fokus penelitian, memilih informan sebagai sumber data, melaksanakan pengumpulan data, merancang aplikasi, dan membuat kesimpulan atas penelitian yang sudah dilakukan.

\subsection{Analisis Kebutuhan Aplikasi dan Perancangan Aplikasi}

Analisis kebutuhan merupakan langkah awal untuk menentukan perangkat lunak yang dihasilkan. Perangkat lunak yang baik dan sesuai dengan kebutuhan pengguna sangat tergantung kepada keberhasilan dalam melakukan analisis kebutuhan. Jika terjadi kesalahan analisis dalam kebutuhan, maka perangkat yang dibuat menjadi tidak berguna. (Tabrani, 2017).

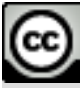

\section{(i)}

Ciptaan disebarluaskan di bawah Lisensi Creative Commons Atribusi 4.0 Internasional.

http://journal.stmikjayakarta.ac.id/index.php/JMIJayakarta 
DOI: $10.52362 /$ jmijayakarta.v1i2.448

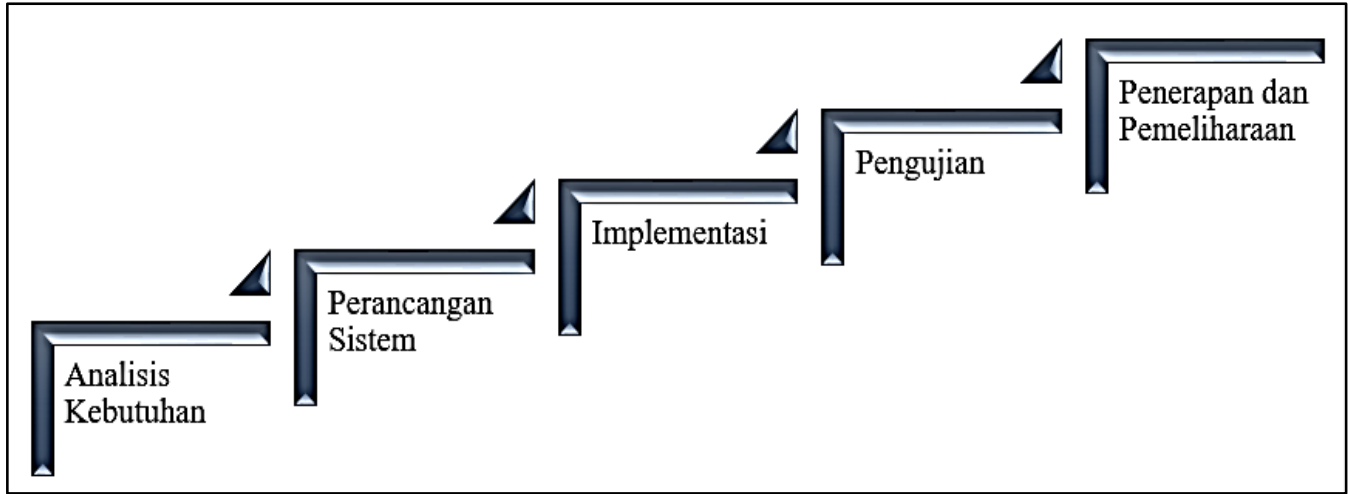

\subsection{Gambaran Umum Sistem}

Gambar 3.2 Metode Waterfall

Rute wisata kuliner menggunakan Algoritma Dijkstra yang dibahas pada penelitian ini adalah aplikasi yang dijalankan pada smartphone android. Aplikasi ini menggunakan Bahasa pemrograman PHP sebagai web service antara aplikasi di android dengan MySQL sebagai database. Aplikasi ini berbasis pada client-server dimana client melakukan request akses untuk menampilkan data dan rute wisata kuliner dari server yang meliputi database, kemudian server akan memberikan respon kepada client data nama kuliner dan rute wisata kuliner. Berikut ini merupakan gambaran alur kerja sistem yang akan dibuat.

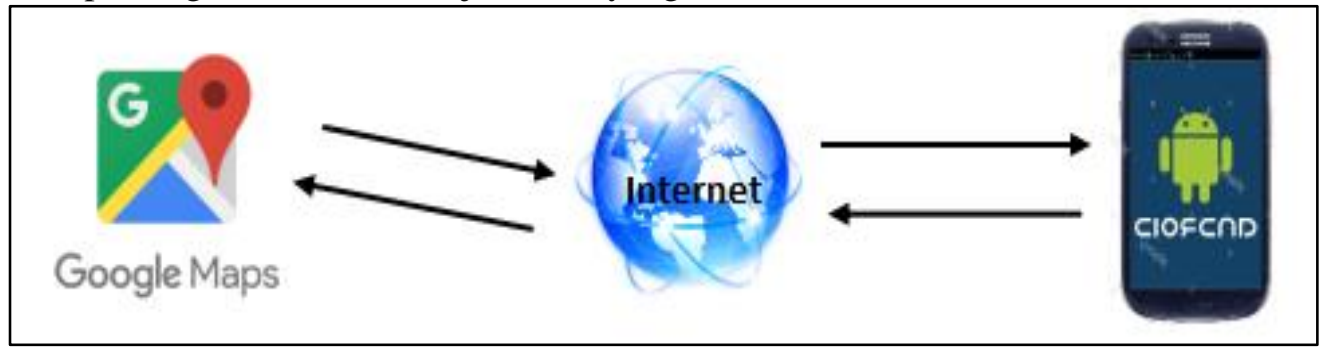

\subsection{Analisis Sistem Berjalan}

\section{Gambar 3.3 Alur Sistem yang Bekerja}

Analisis SWOT merupakan metode perancangan strategis yang berfungsi untuk membuat kerangka situasi dan kondisi pada suatu usaha berdasarkan sudut pandang kekuatan, kelemahan, kesempatan, dan ancaman. Analisis SWOT ini berguna untuk menentukan strategi demi keberlangsungan bisnis di masa depan. Analisis situasi dan kondisi usaha kuliner pada rancangan aplikasi ini disajikan dalam tabel Strengths, Opportunities, Weakness, dan Threats (SWOT) berikut ini.

Tabel 1 Faktor Sistem Berjalan pada Wisata Kuliner

\begin{tabular}{|c|c|}
\hline \multicolumn{2}{|c|}{ Faktor Internal } \\
\hline Strengths (Kekuatan) & Weakness (Kelemahan) \\
\hline $\begin{array}{l}\text { 1. Harga produk terjangkau oleh } \\
\text { semua kalangan masyarakat. } \\
\text { 2. Memiliki banyak pilihan rasa. } \\
\text { 3. Memiliki kualitas cita rasa yang } \\
\text { berbeda. } \\
\text { 4. Pelayanan baik dan ramah. } \\
\text { 5. Akses mudah dijangkau. }\end{array}$ & $\begin{array}{l}\text { 1. Kurangnya promosi atau periklanan. } \\
\text { 2. Lahan parkir sempit. } \\
\text { 3. Tidak tersedia wifi. } \\
\text { 4. Menu makanan dan minuman } \\
\text { monoton. } \\
\text { 5. Pelayanan kurang cekatan. } \\
\text { 6. Teknologi kurang dimanfaatkan }\end{array}$ \\
\hline
\end{tabular}

\section{(7)}


DOI: $10.52362 / j m i j a y a k a r t a . v 1 i 2.448$

\begin{tabular}{|c|c|}
\hline & dengan baik. \\
\hline \multicolumn{2}{|c|}{ Faktor Eksternal } \\
\hline Opportunities (Peluang) & Threats (Ancaman) \\
\hline 1. Bahan baku mudah diperoleh. & 1. Fluktuasi harga bahan baku. \\
\hline 2. Adanya peningkatan jumlah & 2. Munculnya pesaing baru. \\
\hline pelanggan setiap tahun. & 3. Kenaikan Upah Minimum Regional \\
\hline 3. Letaknya strategis. & (UMR) karyawan. \\
\hline 4. Daya beli masyarakat meningkat. & 4. Adanya pungutan liar. \\
\hline
\end{tabular}

Berdasarkan analisis faktor usaha di atas, maka penulis memberikan beberapak alternatif solusi pada usaha kuliner yang diteliti. Berikut ini beberapa solusi yang memungkinkan berdasarkan faktor SWOT.

Tabel 2 Alternatif Solusi dari faktor SWOT

\begin{tabular}{|c|c|c|}
\hline Eks Int & Strengths & Weakness \\
\hline \multirow[t]{3}{*}{ Opportunities } & S-O & W-O \\
\hline & $\begin{array}{l}\text { 1. Mempertahankan harga } \\
\text { dan kualitas rasa guna } \\
\text { mempertahankan loyalitas } \\
\text { pelanggan. }\end{array}$ & $\begin{array}{l}\text { 1. Menggencarkan aktivitas } \\
\text { periklanan secara daring } \\
\text { maupun luring. }\end{array}$ \\
\hline & $\begin{array}{l}\text { 2. } \\
\text { pelakukan inovasi dan } \\
\text { pengembangan cita rasa } \\
\text { produk dan peningkatan } \\
\text { pelayanan. }\end{array}$ & \begin{tabular}{|llr} 
2. & Melakukan & inovasi \\
dengan memasukkan \\
restoran ke dalam \\
teknologi informasi.
\end{tabular} \\
\hline \multirow[t]{4}{*}{ Threats } & S-T & W-T \\
\hline & $\begin{array}{l}\text { 1. Memperkenalkan menu } \\
\text { unik dan bergizi tinggi } \\
\text { kepada masyakarat melalui } \\
\text { promosi dan diskon. }\end{array}$ & $\begin{array}{llr}\text { 1. } & \begin{array}{l}\text { Meminimalkan } \\
\text { produksi } \\
\text { efisiensi. }\end{array} & \text { biaya } \\
\text { melalui }\end{array}$ \\
\hline & $\begin{array}{l}\text { 2. Menjaga ciri khas } \\
\text { kenyamanan tempat dan } \\
\text { keunikan cita rasa agar } \\
\text { berkesan untuk pelanggan. }\end{array}$ & $\begin{array}{llr}\text { 2. } & \begin{array}{l}\text { Menjaga } \\
\text { dengan } \\
\text { sekitar. }\end{array} & \text { lingkungangan } \\
\end{array}$ \\
\hline & $\begin{array}{l}\text { 3. Mengoptimalkan layanan } \\
\text { layanan untuk pelanggan. }\end{array}$ & $\begin{array}{l}\text { 3. Menjaga stabilitas cita } \\
\text { rasa pada setiap } \\
\text { makanan. }\end{array}$ \\
\hline
\end{tabular}

3.5 Perancangan Sistem

\subsubsection{Use Case Diagram}

Use case diagram menggambarkan skenario interaksi antara pengguna (aktor) dengan sistem pada aplikasi. Berikut use case diagram pada aplikasi ini. 
DOI: $10.52362 /$ jmijayakarta.v1i2.448

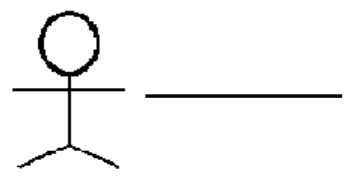

Gambar 3.5 Use Case Diagram

Use case sistem yang diusulkan pada rancangan ini adalah User dapat membuka membuka menu map, menu kuliner, menu about, dan menu exit. Keempat menu tersebut tercakup di menu utama dalam aplikasi ini. User tidak perlu mengakses proses lain untuk menuju ke Menu update current location, Peta, About, dan Exit pada aplikasi ini. Sedangkan user perlu mengakses proses lain untuk menuju menu Kuliner.

\subsection{Class Diagram}

Class diagram menggambarkan clas-class yang perlu dibuat pada aplikasi ini. Terdapat lima class pada rancangan aplikasi ini, yakni menu utama, map, kuliner, about (tentang), dan exit. Class menu utama digunakan untuk menyusun menu-menu pada aplikasi. Class map digunakan untuk menyimpan lokasi wisata kuliner. Class kuliner digunakan untuk menyimpan informasi kuliner, detail kuliner, dan rute Dijkstra.

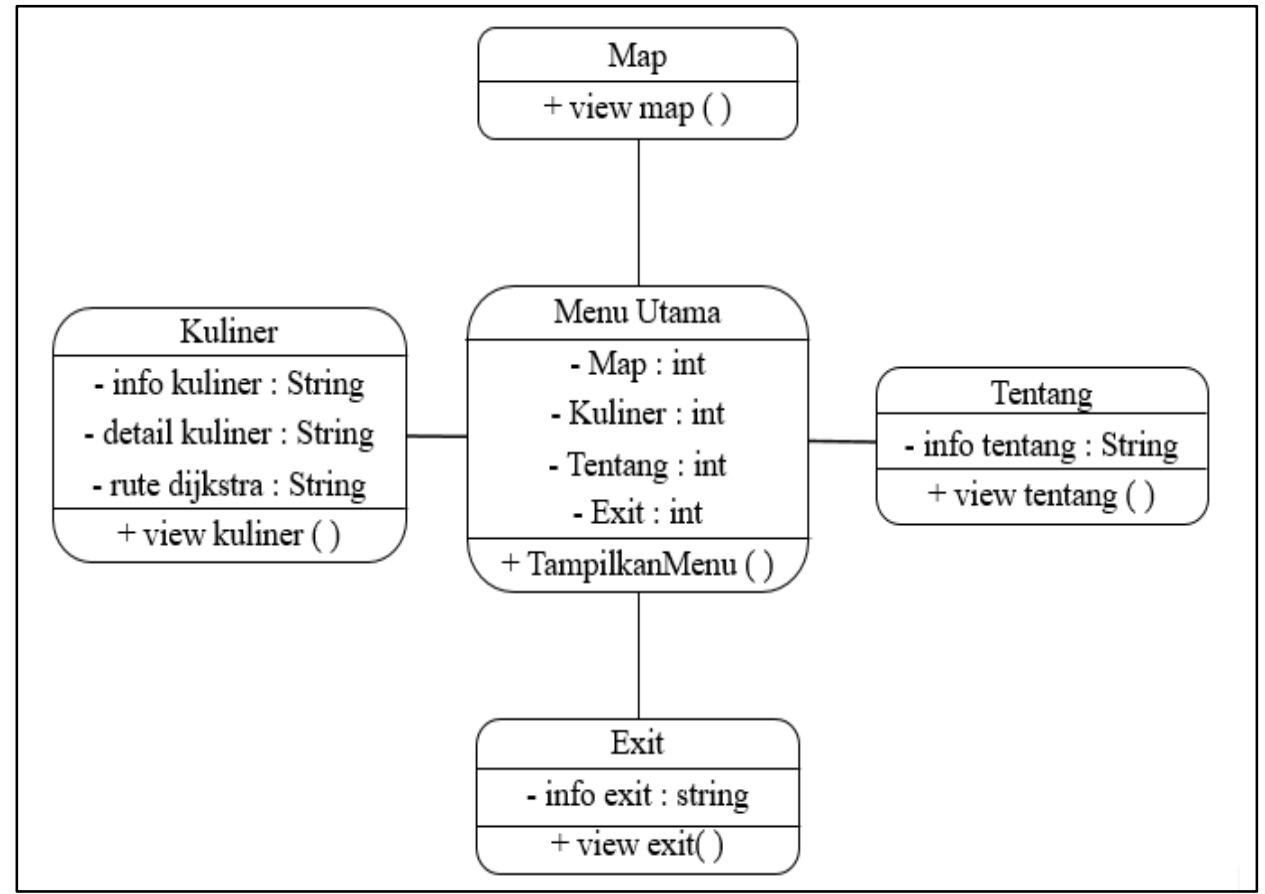

Gambar 3.6 Class Diagram 


\subsection{Analisis Activity Diagram}

DOI: 10.52362/jmijayakarta.v1i2.448

Diagram aktivitas pada aplikasi ini adalah sebagai berikut.

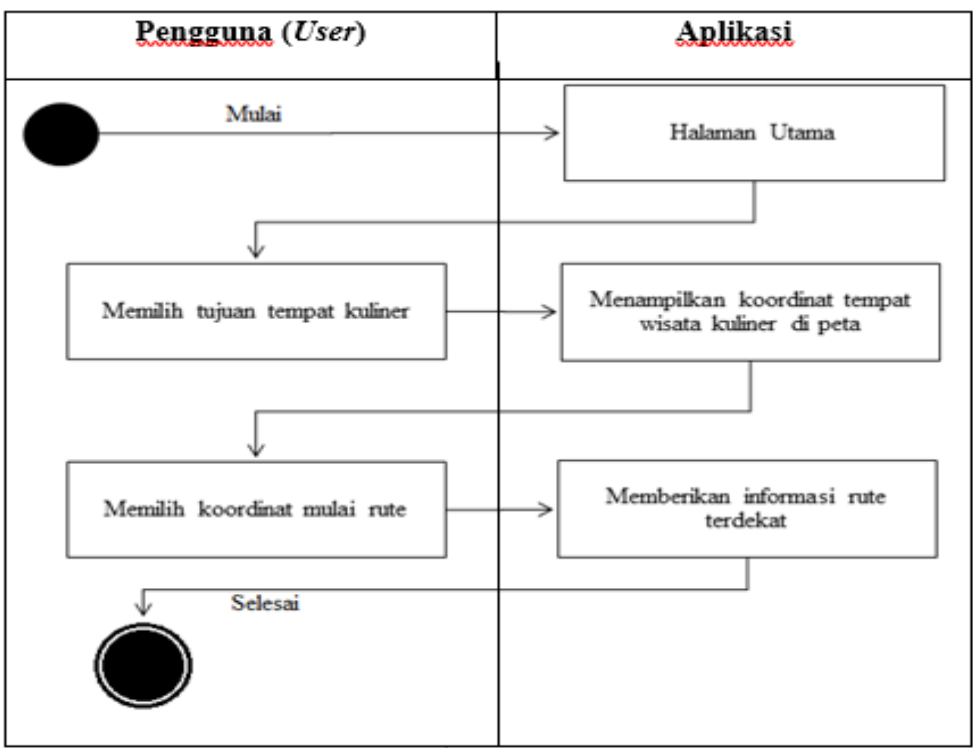

Gambar 3.7 Acvtivity Diagram

User membuka aplikasi dan memulai loading sistem. Setelah itu, halaman utama pada aplikasi terbuka dan muncul menu utama dari aplikasi. Lalu, user memilih tujuan tempat kuliner dan aplikasi menampilkan koordinat tempat kuliner yang terdapat di peta. Kemudian, user memilih koordinat dan memulai rute lokasi wisata kuliner

\subsection{Graf}

Berikut ini hasil gambaran vertex antar wilayah kuliner:

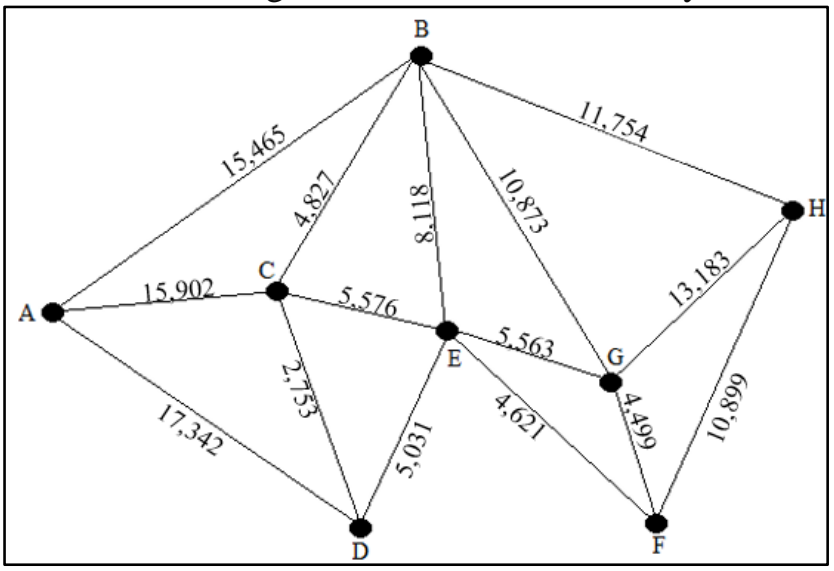

Gambar 3.8 Graf

Graf di atas merepresentasikan jarak-jarak antar daerah wisata kuliner yang ada di Kota Tangerang Selatan. Setiap node saling dihubungkan satu dengan yang lainnya dengan egde. Setiap edge memiliki jarak bersatuan kilometer $(\mathrm{km})$.

\subsection{Perancagnan Database}

Perancangan database bertujuan untuk mengetahui informasi terkait kebutuhan-kebutuhan user dan aplikasi, sehingga lebih mudah dimengerti dan tertata rapi ketika pembuatan basis data pada aplikasi ini. Berikut ini merupakan struktur perancangan database pada aplikasi rute wisata kuliner.

\section{(i)}


DOI: 10.52362/jmijayakarta.v1i2.448

Tabel 3 Rancangan Database Aplikasi

\begin{tabular}{|l|l|c|c|}
\hline \multicolumn{1}{|c|}{ Elemen Data } & \multicolumn{1}{|c|}{ Nama Field } & Tipe & Karakter \\
\hline Kode Kuliner & Kode_kuliner & Varchar & 15 \\
\hline Nama Kuliner & Nama_kuliner & Varchar & 50 \\
\hline Kategori & Kategori & Varchar & 30 \\
\hline Alamat & Alamat & Text & \\
\hline Latitude & Latitude & Double & \\
\hline Longitude & Longitude & Double & \\
\hline Uraian & Uraian & Text & \\
\hline Keterangan & Keterangan & Text & 100 \\
\hline Gambar & Gambar & Varchar & 15 \\
\hline Status & Status & Varchar & 100 \\
\hline Web & Web & Varchar & 15 \\
\hline Telephone & Telephone & &
\end{tabular}

\subsection{Implementasi Sistem}

Pada tahapan ini, aplikasi yang sudah dirancang dan dianalisis dapat dioperasikan sesuai dengan fungsinya masing-masing. Hasil perancangan aplikasi ini diimplemetasikan sebagai berikut.

\subsection{Interface}

a. Interface Splash Screen

Berikut merupakan gambar interface splash screen pada aplikasi ini

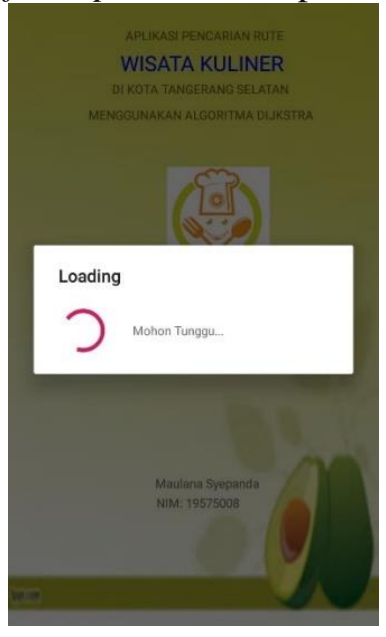

Gambar 3.11

\section{Interface Splash Screen}

Splash screen menampilkan gambar aplikasi yang baru dibuka dalam rentang waktu empat sampai lima detik. Setelah itu akan muncul interface menu utama didalam Aplikasi. 
DOI: 10.52362/jmijayakarta.v1i2.448

\section{b. Interface Menu Utama}

Setelah splash screen selesai tampil, maka akan muncul menu utama pada aplikasi ini. User dapat melihat ada icon Map, Kuliner, About dan Exit.

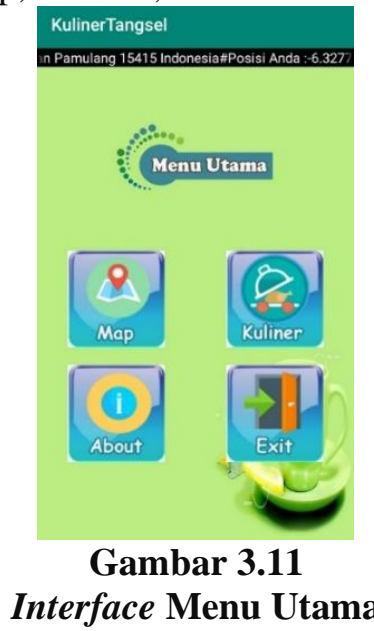

c. Interface Map (Peta)

\section{Interface Menu Utama}

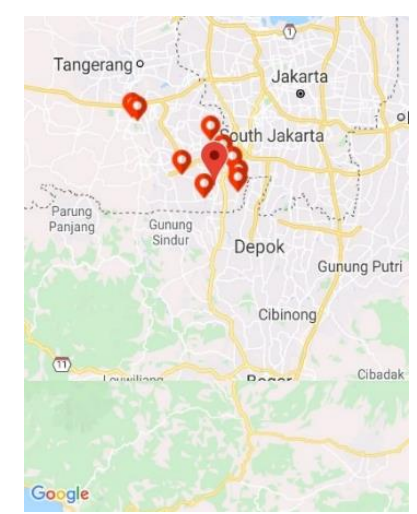

\section{Gambar 3.11 Interface Map}

Ketika User memilih icon Peta pada Aplikasi Kuliner maka akan muncul titi-titik lokasi yang ada di Kota Tangerang Selatan. Terdapat sepuluh lokasi Kuliner di Aplikasi ini

\section{d. Interface Kuliner}

Berikut tampilan menu kuliner pada aplikasi ini.

Soto Ayam SBY (Makanan)

Alamat : Jalan Kedaung, Tangerang Selatan, Banten $(1.0 \mathrm{~km})>$

Kedai Erte (Makanan)

082113590324 Alamat : jalan srikandi ( pamulang, tangerang $>$

Warkop Berkah (Makanan)

082122323039 Alamat : Jl. Cabe II, Pd. Cabe Hitr, Kec. Pamulang

Angkringan \& Roti Bakar (Makanan)

Alamat : Jalan Cempaka Putih, Tangerang Selatan, Banten (3.8.

Basecamp Cafe (Makanan)

087871800286 Alamat : jalan pisangan, Tangerang Selatan, $>$

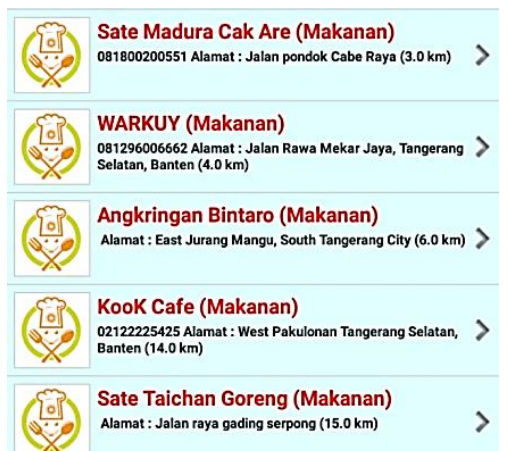

Gambar 3.11

Ciptaan disebarluaskan di bawah Lisensi Creative Commons Atribusi 4.0 Internasional.

http://journal.stmikjayakarta.ac.id/index.php/JMIJayakarta 
DOI: 10.52362/jmijayakarta.v1i2.448

Interface Daftar Kuliner

e. Interface Detail Kuliner

Berikut ini tampilan detail kuliner I dan II.

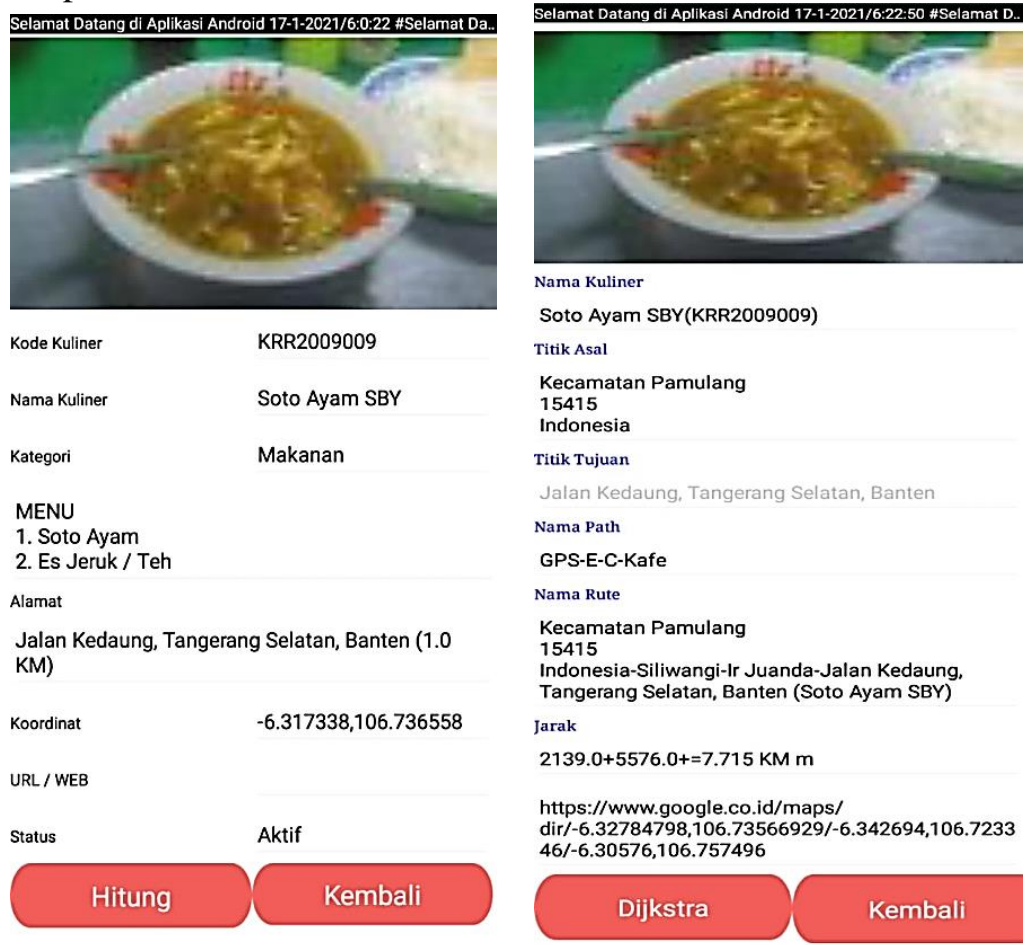

Gambar 3.11

Interface Detail Kuliner

\section{f. Interface About}

Berikut tampilan About ketika User memilih icon About maka akan muncul di Aplikasi seperti ini.

\section{Tentang Aplikasi}

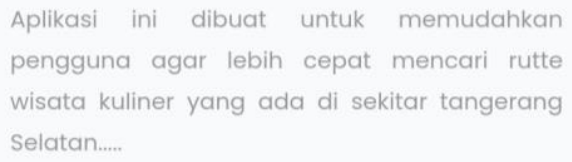

\section{Gambar 3.11 Interface About}

\section{g. Interface Navigasi}

Berikut tampilan navigasi pada aplikasi ini. 
DOI: $10.52362 /$ jmijayakarta.v1i2.448

$\leftarrow$ O Rumahviasi2, Go

O Jl. Siliwangi, Pamulang Bar, K..

๑) J. Ir H. Juanda 26-59, Cireund.

日 $27 \mathrm{~min} \quad$ 目

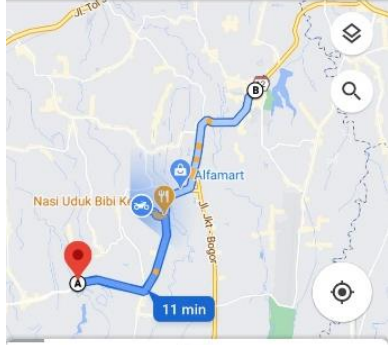

11 min to Jl. Siliwangi, Pamulang Bar... $3.9 \mathrm{~km}$

\section{Gambar 4.21 Interface Navigasi}

Halaman navigasi akan menampilkan rute wisata kuliner yang telah dipilih. Simbol kendaraan pada navigasi menunjukkan tiitk awal (starting point) dan Titik A adalah titik akhir (end point). Titik B pada navigasi menunjukkan wilayah yang terdekat dengan titik awal dan titik akhir.

h. Interface Konfirmasi Exit (Keluar)

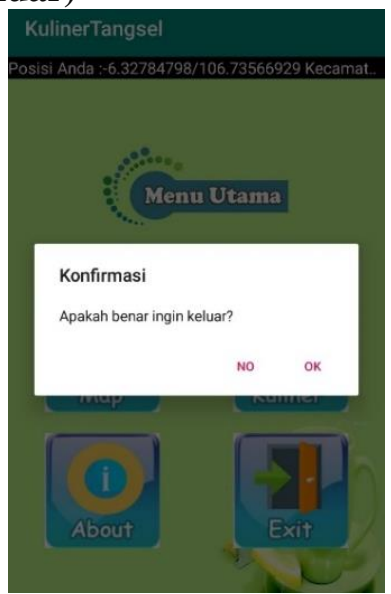

i. Interface Menutup Aplikasi

Gambar 3.11

Tampilan menutup Aplikasi j

Interface Exit

terdapat tulisan "Terima kasih.. Anda telan menggunakan Aplikasi ini”. 
DOI: $10.52362 / j m i j a y a k a r t a . v 1 i 2.448$

3.12 Pengujian Sistem

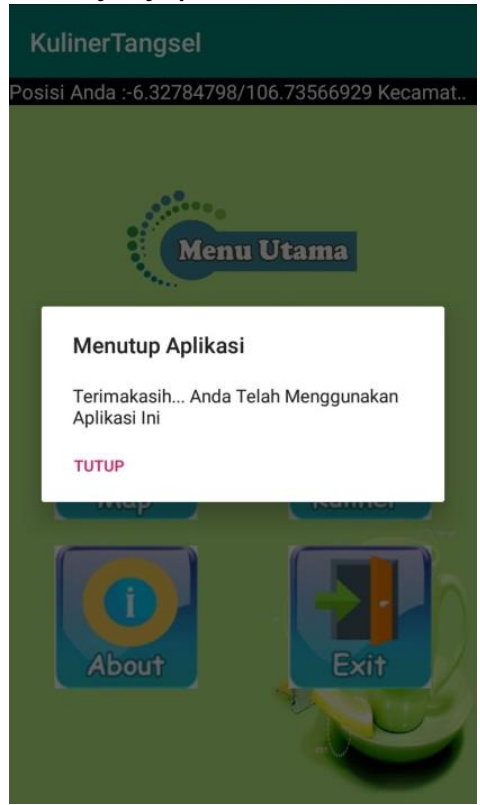

Gambar 3.11

Interface Menutup Aplikasi

\section{a Pengujian Algoritma Dijkstra}

Pengujian perhitungan algoritma Dijkstra pada peta yang terdapat di aplikasi ini dilakukan pada setiap tujuan wisata kuliner dengan masing-masing uji coba melalui empat rute yang berbeda. Algoritma Dijkstra akan menentukan jarak terpendek yang akan menjadi rute user menuju ke lokasi kuliner. Berikut ini hasil pengujian algoritma Dijkstra.

Tabel 4 Uji Coba I Algoritma Dijkstra

\begin{tabular}{|l|l|}
\hline \multicolumn{2}{|c|}{ PENGUJIAN I } \\
\hline \multicolumn{2}{|c|}{ Koordinat Awal : $\mathbf{- 6 . 1 9 7 7 8 8 4 , ~ 1 0 6 . 8 5 1 7 6 1 0}$} \\
\hline \multicolumn{2}{|c|}{ Koordinat Tujuan : -6.3254743, 106.7665868 } \\
\hline \multicolumn{2}{|c|}{ Wisata Kuliner : Warkop Berkah } \\
\hline Relasi Vertex 1: A-D & 17.342 meter \\
\hline Relasi Vertex 2: A-C-D & 18.655 meter \\
\hline Relasi Vertex 3: A-B-C-D & 23.945 meter \\
\hline Relasi Vertex 4: A-C-E-D & 26.509 meter \\
\hline Relasi Vertex Terpilih : A-D $=\mathbf{1 7 . 3 4 2}$ meter \\
\hline
\end{tabular}

Jalur pertama pada pengujian I adalah vertex 1 yang memiliki panjang 17.342 meter, dan jalur kedua adalah relasi vertex 2 yang memiliki panjang 18.655 meter. Algoritma Dijkstra menyimpulkan jarak terpendek adalah relasi vertex 1 yakni vertex A-D.

Tabel 5 Uji Coba II Algoritma Dijkstra

\begin{tabular}{|l|l|}
\hline \multicolumn{2}{|c|}{ PENGUJIAN II } \\
\hline \multicolumn{2}{|c|}{ Koordinat Awal : -6.1977884, 106.8517610 } \\
\hline \multicolumn{2}{|c|}{ Koordinat Tujuan : -6.3083907, 106.7588419 } \\
\hline \multicolumn{2}{|c|}{ Wisata Kuliner : Best Camp Café } \\
\hline Relasi Vertex 1: A-D-C & 20.095 meter \\
\hline Relasi Vertex 2: A-C & 15.902 meter \\
\hline
\end{tabular}


DOI: 10.52362/jmijayakarta.v1i2.448

\begin{tabular}{|l|l|}
\hline Relasi Vertex 3: A-B-C & 20.292 meter \\
\hline Relasi Vertex 4: A-D-E-C & 27.949 \\
\hline \multicolumn{2}{|c|}{ Relasi Vertex Terpilih : A-C $=\mathbf{1 5 . 9 0 2}$ meter } \\
\hline
\end{tabular}

Jalur pertama pada pengujian II adalah vertex 1 yang memiliki panjang 20.095 meter, dan jalur kedua adalah relasi vertex 2 yang memiliki panjang 15.902 meter. Algoritma Dijkstra menyimpulkan jarak terpendek adalah relasi vertex 2 yakni vertex A-C.

\section{Tabel 6 Uji Coba III Algoritma Dijkstra}

\begin{tabular}{|l|l|}
\hline \multicolumn{2}{|c|}{ PENGUJIAN III } \\
\hline \multicolumn{2}{|c|}{ Koordinat Awal : $\mathbf{- 6 . 1 9 7 7 8 8 4 , ~ 1 0 6 . 8 5 1 7 6 1 0}$} \\
\hline \multicolumn{2}{|c|}{ Koordinat Tujuan : -6.2444090, 106.6373210 } \\
\hline \multicolumn{2}{|c|}{ Wisata Kuliner : Kook Café } \\
\hline Relasi Vertex 1: A-C-E-G-H & 40.224 meter \\
\hline Relasi Vertex 2: A-B-H & 27.219 meter \\
\hline Relasi Vertex 3: A-D-E-G-H & 41.119 meter \\
\hline Relasi Vertex 4: A-C-E-F-H & 36.998 meter \\
\hline \multicolumn{2}{|c|}{ Relasi Vertex Terpilih : A-B-H $=\mathbf{2 7 . 2 1 9}$ meter } \\
\hline
\end{tabular}

Jalur pertama pada pengujian III adalah vertex 2 yang memiliki panjang 27.219 meter, dan jalur kedua adalah relasi vertex 4 yang memiliki panjang 36.998 meter. Algoritma Dijkstra menyimpulkan jarak terpendek adalah relasi vertex 2 yakni vertex A-B-H

\subsection{Pengujian Black Box}

Pengujian black box pada aplikasi pencarian rute terpendek pada wisata kuliner di Kota Tangerang Selatan dilakukan untuk mengetahui kesesuaian antara aplikasi yang sudah dirancang sebelumnya dengan spesifikasi sistem dan lingkungan yang diharapkan. Pengujian dilakukan dengan cara menguji setiap proses dengan menggunakan black box yang menguji perangkat lunak berdasarkan spesifikasi fungsinonal. Pengujian black box tidak menguji desain dan dan kode program. Berikut merupakan hasil pengujian black box pada aplikasi ini.

Tabel 7 Pengujian Black Box pada Smartphone Android

\begin{tabular}{|c|l|l|c|}
\hline No. & \multicolumn{1}{|c|}{$\begin{array}{c}\text { Pengujian } \\
\text { Aplikasi }\end{array}$} & \multicolumn{1}{|c|}{ Hasil yang Diharapkan } & Hasil \\
\hline 1 & $\begin{array}{l}\text { Masuk ke } \\
\text { Splash Screen }\end{array}$ & $\begin{array}{l}\text { Menampilkan nama aplikasi serta } \\
\text { proses loading ke menu utama }\end{array}$ & OK \\
\hline 2 & $\begin{array}{l}\text { Masuk ke menu } \\
\text { utama }\end{array}$ & $\begin{array}{l}\text { Menampilkan empat menu yang dapat } \\
\text { di akses } \text { user }\end{array}$ & OK \\
\hline 3 & $\begin{array}{l}\text { Memilih menu } \\
\text { Wisata Kuliner }\end{array}$ & $\begin{array}{l}\text { Menampilkan kolom input jarak dan } \\
\text { list berupa daftar wisata kuliner }\end{array}$ & OK \\
\hline 4 & $\begin{array}{l}\text { Kemilih } \\
\text { Kuliner }\end{array}$ & $\begin{array}{l}\text { Menampilkan informasi Kuliner } \\
\text { rute }\end{array}$ & $\begin{array}{l}\text { Menampilkan rute menuju wisata } \\
\text { kuliner }\end{array}$ \\
\hline
\end{tabular}


DOI: 10.52362/jmijayakarta.v1i2.448

\begin{tabular}{|c|lc|l|c|}
\hline 6 & $\begin{array}{l}\text { Memilih menu } \\
\text { map }\end{array}$ & $\begin{array}{l}\text { Menampilkan peta titik-titik wisata } \\
\text { kuliner }\end{array}$ & OK \\
\hline 7 & $\begin{array}{l}\text { Memilih menu } \\
\text { About }\end{array}$ & $\begin{array}{l}\text { Menampilkan tentang penggunaan } \\
\text { aplikasi. }\end{array}$ & OK \\
\hline 8 & $\begin{array}{l}\text { Memilih menu } \\
\text { exit }\end{array}$ & $\begin{array}{l}\text { Menampilkan tanda user untuk keluar } \\
\text { aplikasi }\end{array}$ & OK \\
\hline
\end{tabular}

\section{KESIMPULAN}

Berdasarkan hasil penelitian di lapangan dan proses pembuatan aplikasi yang penulis lakukan, maka didapatkan kesimpulan sebagai berikut:

a. Penikmat kuliner yang berasal dari dalam maupun luar kota dapat mengetahui lokasi wisata kuliner yang terletak di Kota Tangerang Selatan menggunakan aplikasi kuliner berbasis android yang sudah dikembangkan dengan mudah dan efisien.

b. Penikmat kuliner tidak lagi membutuhkan waktu yang lama untuk menemukan lokasi wisata kuliner yang ada di Kota Tangerang Selatan karena menggunakan aplikasi rute wisata kuliner ini.

c. Penikmat kuliner dapat menentukan rute tercepat menuju ke lokasi wisata kuliner dengan aplikasi ini, sehingga lebih efektif dan efisien.

4.1 Saran

a. Diharapkan pengembangan aplikasi ini dapat menggunakan bahasa pemograman lain, sehingga dapat mengatasi keterbatasan operating system dan dapat digunakan di semua jenis smartphone.

b. Perlu dilakukan penambahan informasi lokasi wisata di Tangerang Selatan, sehingga semakin banyak wisata kuliner yang menjadi sampel pada aplikasi berikutnya.

c. Pengembangan aplikasi ini selanjutnya diharapkan dapat menggunakan algoritma lain yang lebih kompleks.

\section{REFERENASI}

[1] Al Amin, Imam Husni. 2017. Visualisasi Pencarian Lintasan Terpendek Algoritma Floydwarshall Dan Dijkstra Menggunakan Tex. Prosiding SINTAK 2017 Unisbank.

[2] Ardana, Dwi dan Ragil Saputra. 2016. Penerapan Algoritma Dijkstra pada Aplikasi Pencarian Rute Bus Trans Semarang. Jurnal Seminar Nasional Ilmu Komputer. Universitas Diponegoro.

[3] Budihartanti, Cahyani. 2016. Rancang Bangun Aplikasi Android Pencarian Rumah Kait di Jakarta Menggunakan Algoritma Dijkstra. Jurnal PROSISKO Vol.3 No.2.

[4] Cholifah, Wahyu Nur, dkk. 2018. Pengujian Black Box Testing pada Aplikasi Action \& Strategy Berbasis Android dengan Teknologi Phonegap. Jurnal String Vol.3 No.2.

[5] Djafar, Imran. 2016. Pembangunan Aplikasi Location Based Service (LBS) Kota Makassar. Seminar Nasional Teknologi Informasi dan Multimedia.

[6] Habibi, Roni. dkk. 2020. Aplikasi Kehadiran Dosen menggunakan PHP OOP. Bandung: Kreatif Industri Nusantara.

[7] Kementerian Pariwisata Republik Indonesia. 2019. Pedoman Pengembangan Wisata Kuliner.

[8] Mufti, Y. 2015. Panduan Mudah Pengembangan Google Map Android. Yogyakarta: Penerbit Andi.

[9] Munir, Rinaldi. 2016. Matematika Diskrit. Revisi Keenam. Bandung: Informatika.

\section{(i)} Ciptaan disebarluaskan di bawah Lisensi Creative Commons Atribusi 4.0 Internasional. http://journal.stmikjayakarta.ac.id/index.php/JMIJayakarta 
DOI: $10.52362 /$ jmijayakarta.v1i2.448

[10] Nugroho, A. 2010. Rekayasa Perangkat Lunak Menggunakan UML \& Java. Yogyakarta: Andi Offset.

[11] Palit, Randi V. 2015. Rancangan Sistem Informasi Keuangan Gereja Berbasis Web di Jemaat GMIM Bukit Moria Malalayang. E-Journal Teknik Elektro dan Komputer Vol 4, No.7.

[12] Pambudi, Dany. 2014. Aplikasi Mobile Penentuan Rute Terpendek di Kebun Raya Bogor Mengunakan Alrogitma Dijkstra. Skripsi Jurusan Ilmu Komputer IPB Bogor.

[13] Purwaningsih, Fitri. 2017. Penerapan Algoritma Huffman untuk Aplikasi Pengamanan SMS Berbasis Android. Jurnal PROSISKO Vol. 4 No. 2.

[14] Putra, Dede Wira Trise. 2019. Unified Modelling Language (UML) dalam Perancangan Sistem Informasi Permohonan Pembayaran Restitusi SPPD. Jurnal TEKNOIF Vol. 7 No. 1.

[15] Rumondor, Aryando Giovani. 2019. Perancangan Jalur Terpendek Evakuasi Bencana di Kawasan Boulevard Manado Menggunakan Algoritma Dijkstra. Jurnal Teknik Informatika Vol 14, No.2 Universitas Sam Ratulangi.

[16] Safaat, N. 2011. Pemrograman Aplikasi Mobile Smartphone dan Tablet PC Berbasis Android. Bandung: Informatika.

[17] Standsyah, Rahmawati Erma. 2017. Implementasi PhpMyAdmin pada Rancangan Sistem Pengoperasian. Jurnal UJMC Vol 3, No.2.

[18] Susetyo, Yerymia Alfa. 2018. Pembangunan Sistem Informasi Zona Potensi Sumber Daya Kelautan Kabupaten Gunungkidul Berbasis HMVC Menggunakan Google Maps API dan JSON. Indonesian Journal of Modeling and Computing 2.

[19] Tabrani, Muhamad. 2017. Penerapan Metode Waterfall pada Sistem Informasi Inventori PT. Pangan Sehat Sejahtera. Jurnal Infokar Vol.1 No.2.

[20] Taryadi. 2016. Aplikasi Pencarian Tempat Wisata Kuliner di kota Pekalongan berbasis Location Based Service dan Geotagging pada Android. Jurnal LITBANG Kota Pengalongan Vol. 10.

[21] Yudhanto, Yudho dan Ardhi Wijayanto. 2019. Yuk Berbisnis dengan Laravel dan Android. Jakarta: Gramedia.

[22] BKPP Kota Tangerang Selatan. Sejarah Kota Tangerang Selatan. Diakses pada 9 November 2020. http://bkpp.tangerangselatankota.go.id/v4/profile/sejarah.

[23] Hera. 2020. Pengertian Android SDK. Diakses pada 2 Oktober 2020. http://itlearningcenter.id/pengertian-android-sdk/

[24] Kamus Besar Bahasa Indonesia. 2003. Diakses pada 9 Oktober 2020.

[25] Undang-Undang Nomor 10 Tahun 2019 tentang Industri Pariwisata.

[26] Benni Triyono, Sri Purwanti, Verdi Yasin (2017) "Rekayasa Perangkat Lunak Sistem Informasi Pengiriman Dan Penerimaan Surat Atau Paket Berbasis Web", Journal of Information System, Applied, Management, Accounting and Research, e-ISSN: 2598-8719. p-ISSN: 2598-8700.Vol.1 No.1 (30 Desember 2017) p46-53 http://iournal.stmikjayakarta.ac.id/index.php/iisamar/article/view/12

[27] Verdi Yasin, Muhammad Zarlis, Mahyuddin K.M. Nasution (2018) "Filsafat Logika Dan Ontologi Ilmu Komputer", Journal of Information System, Applied, Management, Accounting and Research, e-ISSN: 2598-8719. p-ISSN: 2598-8700.Vol.2 No.2 (19 Juni 2018) p68-75 http://journal.stmikjayakarta.ac.id/index.php/jisamar/article/view/39

[28] Julinda Maya Paramudita, Verdi Yasin (2019) "Perancangan Aplikasi Sistem Penyewaan Alat Berat ", Journal of Information System, Applied, Management, Accounting and Research, e-ISSN: 25988719. p-ISSN: 2598-8700.Vol.3 No.1 (20 Februari 2019) p23-29 http://journal.stmikjayakarta.ac.id/index.php/jisamar/article/view/73

[29] Muryan Awaludin, Verdi Yasin (2020) "Application Of Oriented Fast And Rotated Brief (Orb) And Bruteforce Hamming In Library Opencv For Classification Of Plants", Journal of Information System, Applied, Management, Accounting and Research, e-ISSN: 2598-8719. p-ISSN: 25988700.Vol.4 No.3 (14 Agustus 2020) p51-59 http://journal.stmikjayakarta.ac.id/index.php/iisamar/article/view/247

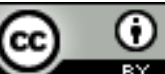

